\title{
Growth, Nodulation, and Yield Responses of Groundnut (Arachis hypogaea L.) as Influenced by Combined Application of Rhizobium Inoculant and Phosphorus in the Guinea Savanna Zone of Ghana
}

\author{
Michael Asante $\mathbb{D}^{D}$, Benjamin Dzorgbenyui Kofi Ahiabor, and Williams K. Atakora \\ CSIR-Savanna Agricultural Research Institute, P. O. Box TL 52, Tamale, Ghana \\ Correspondence should be addressed to Michael Asante; mkasante08@yahoo.co.uk
}

Received 24 October 2019; Revised 30 January 2020; Accepted 6 February 2020; Published 31 March 2020

Academic Editor: Iskender Tiryaki

Copyright (c) 2020 Michael Asante et al. This is an open access article distributed under the Creative Commons Attribution License, which permits unrestricted use, distribution, and reproduction in any medium, provided the original work is properly cited.

\begin{abstract}
Groundnut yields obtained by farmers in northern Ghana are generally low due to low soil fertility resulting from continuous cropping coupled with low use of external inputs. There is therefore the need to use systems' internal resources such as biological nitrogen fixation efficiently to enhance crop production. This on-station experiment investigated nodulation and pod yield responses of three groundnut varieties, namely Obolo, Oboshie and Samnut 22 to inoculation with rhizobium inoculants of exotic strains, namely Bradyrhizobium yuanmingense (BR 3267) and USDA 3456 in combination with $0 \mathrm{~kg}^{\mathrm{P}}$ ha ${ }^{-1}$, $15 \mathrm{~kg} \mathrm{P} \mathrm{ha}^{-1}$ and $30 \mathrm{~kg} \mathrm{P} \mathrm{ha}^{-1}$. Combined application of $30 \mathrm{~kg} \mathrm{P} \mathrm{ha}^{-1}$ and BR 3267 increased the nodule numbers in Obolo, Oboshie and Samnut 22 by $144 \%, 188 \%$ and $56 \%$, respectively compared to their uninoculated counterparts. Inoculation with BR 3267 produced the highest pod yield in all the three varieties with yields increasing from 13 to $40 \%$ over that of the uninoculated treatments, with BR 3267-inoculated Samnut 22 giving the highest yield of $2013 \mathrm{~kg} \mathrm{ha}^{-1}$. P fertilizer and rhizobium inoculant also had a significant interactive influence on the pod yield of groundnut. Combined application of $30 \mathrm{~kg} P$ $\mathrm{ha}^{-1}$ and rhizobium inoculation increased the groundnut yield by 64 to $68 \%$. The study observed a positive interaction between the rhizobium strains and $\mathrm{P}$ fertilizer.
\end{abstract}

\section{Introduction}

Groundnut (Arachis hypogaea L.) is an important grain legume produced in northern Ghana. The crop is grown mainly for its seed and it comprises $40-50 \%$ oil, $20-30 \%$ protein and contains vitamin $B$ as well. All other parts of the plant are used as animal feed [1]. Poor soil fertility, lack of improved varieties, erratic rainfall and drought are some of the production constraints faced by farmers in northern Ghana. However, poor soil fertility and lack of improved varieties are the predominant production constraints groundnut farmers face in the region although plant breeders have contributed immensely through variety improvement to curb the situation. However, soils found in most groundnut-growing areas are inherently poor with deficiencies in most of the essential plant nutrients especially nitrogen (N) and phosphorus (P) [2]. Groundnut yields obtained by farmers in northern Ghana are generally low due to the poor soil fertility which has ensued as a result of continuous cropping coupled with low use of external inputs. The high cost of inorganic fertilizers coupled with the environmental threat posed by their application is also a major concern. There is therefore, the need to use systems' internal resources such as biological nitrogen fixation (BNF) efficiently and judiciously use $\mathrm{P}$ fertilizers to enhance groundnut production.

Inoculation of legumes with rhizobia generally triggers plant growth, development and yield and it is normally used as a substitute for mineral nitrogen fertilizer which is often costly [3]. The rhizobia (bacteria) have the potential to infect 
the root, form nodules and symbiotically fix $\mathrm{N}_{2}$ in leguminous plants [4]. However, the rhizobium is host-specific as certain species can only infect specific legumes.

The rhizobium activity and $\mathrm{N}_{2}$ fixation are reduced when the system lacks phosphorus $(\mathrm{P})$ since $\mathrm{P}$ serves as energy source for the rhizobia and also stimulates early root growth and enhances the formation of lateral and fibrous root systems which are essential for nodule formation. According to [5], $\mathrm{P}$ enhanced the efficiency of photosynthesis in plants and increased branch numbers and pods per plant thereby contributing to the yield of plants. This notwithstanding, [6] reported that $\mathrm{P}$ is a limiting factor in plant nutrition as a result of the deficit of available soluble phosphate in the soil. Research work by [7] reveals that legumes inoculated with rhizobium in addition to phosphorus fertilizer respond differently in terms of growth, yield and nitrogen fixation. Also, [8] observed that combined application of phosphorus at $45 \mathrm{~kg} \mathrm{P} \mathrm{ha}^{-1}$ plus rhizobium inoculants increased nodulation by $56 \%$ and recorded significant higher soybean grain yields. Their work further revealed that combined application of $45 \mathrm{~kg} \mathrm{P} \mathrm{ha}^{-1}$ and rhizobium inoculant was more profitable than the application of only $45 \mathrm{~kg} \mathrm{P} \mathrm{ha}^{-1}$. In general, this current experiment sought to investigate the response of groundnut to combined application of rhizobium inoculants of different strains and $\mathrm{P}$ fertilizer. Specifically, the study was to determine the appropriate rhizobium strain to enhance nodulation, growth and grain yield of groundnut, to determine whether the response of groundnut to the rhizobium strains is variety-dependent and also to investigate the interactive effects of inoculation and phosphorus application on the above responses of the groundnut varieties.

\section{Materials and Methods}

2.1. Area Description. The study was carried out at the experimental field of the Council for Scientific and Industrial Research-Savanna Agricultural Research Institute (CSIRSARI) in the Northern Region of Ghana. The site is located at $09^{\circ} 23^{\prime} 29.8^{\prime \prime} \mathrm{N}$ and $001^{\circ} 00^{\prime} 04.8^{\prime \prime} \mathrm{W}$. Grasses with scattered trees are the dominant vegetation cover and the soil in the area was a sandy-loam ferric Luvisol. It is a tropical area and has a mean daily temperature of $26^{\circ} \mathrm{C}$ and a unimodal rainfall pattern with a mean annual rainfall of $1100 \mathrm{~mm}$ [9].

2.2. Experimental Design and Treatment Application. The trial was a split-split plot design with three replications. A total number of 81 plots with an individual plotsize of $9 \mathrm{~m}^{2}$ were used. The main plot treatments were three groundnut varieties, namely Samnut 22, Obolo and Oboshie. The subplot treatments include three levels of $P$ fertilizers $(0 \mathrm{~kg} \mathrm{P}$ $\mathrm{ha}^{-1}, 15 \mathrm{~kg} \mathrm{P} \mathrm{ha}^{-1}$ and $30 \mathrm{~kg} \mathrm{P} \mathrm{ha}{ }^{-1}$ ) and sub-subplot treatments comprised two inoculant strains (BR 3267 from Embrapa Agrobiologia, Brazil and USDA 3456 from Nairobi, Kenya) and no inoculant (control). Based on several preliminary experiments on $\mathrm{P}$ optimum dose for groundnut (data unpublished), we observed that $30 \mathrm{~kg} \mathrm{P} \mathrm{ha}^{-1}$ was the optimum for groundnut production in the study area. Going above $30 \mathrm{~kg} \mathrm{P} \mathrm{ha}{ }^{-1}$ would probably not be economically viable for the groundnut farmers in the study area.

2.3. Agronomic Practices. Initial soil samples were taken as composite samples at a depth of $0-20 \mathrm{~cm}$ before treatments application to determine the initial physico-chemical status of the soil at the experimental site. The soil samples were analysed for the following parameters: $\mathrm{pH}\left(\mathrm{H}_{2} \mathrm{O} /\right.$ soil $\left.2: 1\right)$, organic carbon (Walkley-Black), total N (Kjeldahl distillation), $\mathrm{CEC}\left(\mathrm{NH}_{4} \mathrm{OAc}\right)$, available phosphorus (Bray-I), exchangeable $\mathrm{K}\left(\mathrm{NH}_{4} \mathrm{OAc}\right)$, bulk density $\left(3 \times 100 \mathrm{~cm}^{3}\right.$ metal cans per profile depth and replication) and particle size distribution (hydrometric method) [10,11] (Table 1).

The field was previously planted to maize for three years. The land was ploughed and harrowed with a tractor and manually ridged. Seeds of the test groundnut varieties were inoculated as follows: $30 \mathrm{ml}$ of $20 \%$ sugar solution was sprinkled onto $1 \mathrm{~kg}$ of groundnut seeds and mixed thoroughly after which $5 \mathrm{~g}$ of inoculant was added to it and stirred uniformly to ensure adequate coating of every seed with the inoculant material. The mixture was then dried under shade for about 30 minutes after which the inoculated seeds were sown. The groundnut seeds were sown on 26th June, 2016 at a spacing of $50 \times 20 \mathrm{~cm}$ under rain-fed conditions and one plant was maintained per hill. Phosphorus was applied in the form of triple superphosphate $\left(46 \% \mathrm{P}_{2} \mathrm{O}_{5}\right)$ by side placement two weeks after sowing. The field was manually weeded at 2 nd and 5 th weeks after sowing. The groundnut variety, Samnut 22 was obtained from the International Institute of Tropical Agriculture (IITA), Ibadan, Nigeria and the Oboshie and Obolo were obtained from the Crop Research Institute of the Council for Scientific and Industrial Research (CSIR-CRI), Fumesua, Ghana. All the varieties were selected because of their high yielding potential, medium maturity and their availability in the region. Data were recorded on days to $50 \%$ flowering, nodule number, nodule dry weight, pod load, pod yield, haulm weight and seed size (as 100-seed weight).

2.4. Days to $50 \%$ Flowering. It is the number of days from planting to the time when $50 \%$ of the plants had flowered. In order to obtain this, a $4 \mathrm{~m}^{2}$ area was marked in the middle of the plot and the progress of flowering was monitored till the date on which half of the number of plants within this area flowered and this date was recorded.

2.5. Nodulation. Five plants were selected from each of the rows next to the two border rows giving a total of 10 plants. The plants were gently scooped up with a spade and the roots were washed on a sieve under a jet of tap water and then placed on a paper towel in the shade to air-dry. The nodules were then counted while still intact on the roots from the crown to the tip. The total number of nodules from the ten plants was divided by 10 to obtain the number of nodules per plant. The nodules were then carefully detached from the roots of the 10 plants with hand and dried in a forced-air oven at $60^{\circ} \mathrm{C}$ until a constant weight was obtained and this 
TABLE 1: Physical and chemical properties of the soil of the trial site at Nyankpala, northern Ghana.

\begin{tabular}{lc}
\hline Parameter & Value \\
\hline $\mathrm{pH}\left(\mathrm{H}_{2} \mathrm{O}\right)$ & 5.8 \\
$\%$ organic carbon & 0.12 \\
$\%$ total N & 0.02 \\
Available $\mathrm{P}\left(\mathrm{mg} \mathrm{kg}^{-1}\right)$ & 13.28 \\
$\mathrm{~K}\left(\mathrm{mg} \mathrm{kg}^{-1}\right)$ & 89.00 \\
$\mathrm{Ca}\left(\mathrm{Cmol} \mathrm{kg}^{-1}\right)$ & 7.16 \\
$\mathrm{Mg}(\mathrm{Cmol} \mathrm{kg}$ & 1.16 \\
$\%$ sand & 70.72 \\
$\%$ clay & 5.80 \\
\% cilt & 23.48 \\
\hline
\end{tabular}

weight value was divided by 10 to get the nodule dry weight per plant.

2.6. Pod Yield. Plants in the middle four rows of each plot were harvested and the pods pricked from the roots and dried in the sun on a concrete floor for a sufficient number of days and then weighed using a digital balance.

2.7. Pod Load. Five plants were randomly selected from the harvested lot and their pods were detached, counted and the number recorded. This value was averaged over the five plants to obtain the pod load which is defined as the average number of pods produced by one plant.

2.8.100-Seed Weight. In order to determine the average seed size/weight, about 100 pods were randomly selected per treatment, shelled and the seeds were mixed and from this number 100 seeds were picked and weighed to estimate the average seed size/weight.

2.9. Haulm Yield. After removing the pods from the plants harvested from the four inner rows, the leaves and the roots were removed from the plants and the remaining stuff was weighed and recorded as field weight. In order to determine the moisture content of each lot of haulm, a sub-sample of the haulm was taken from each treatment, weighed and oven-dried at $60^{\circ} \mathrm{C}$ to a constant weight. The percent moisture content of the sub-sample and the field weight of the bulk haulm were used to calculate the dry weight of the bulk haulm.

2.10. Data Analysis. The data obtained were subjected to analysis of variance (ANOVA) using GENSTAT $\left(12^{\text {th }}\right.$ Edition) [12] and the means were separated with the least significant difference (LSD) approach at $P<0.05$.

\section{Results and Discussion}

The application of rhizobium inoculants and P fertilizer had great influence on all the three groundnut varieties as most of the variables measured were influenced by these treatments.
3.1. Days to $50 \%$ Flowering. There was no interaction effect on variety, phosphorus and inoculant together on days to $50 \%$ flowering but the interaction of variety and inoculant as well as the interaction of $\mathrm{P}$ fertilizer and inoculant were significant $(P<0.05)$. Inoculation of the three groundnut varieties with both rhizobium strains USDA 3456 and BR 3267 reduced the period of flowering compared to the uninoculated groundnut varieties (Table 2). Inoculation of Oboshie and Obolo with BR 3267 reduced the days to 50\% flowering by $16 \%$ in these varieties compared to the uninoculated plants (Table 2). This could be as a result of the fact that the rhizobium strain applied was effective and may have made more $\mathrm{N}$ available through $\mathrm{N}_{2}$ fixation thereby enhancing the overall nutrition of the plants which might have triggered the early reproductive processes of flowering. The results agree with the findings of [13] who reported that inoculating soybean with rhizobium reduced the days to $50 \%$ flowering compared to the uninoculated plots.

All inoculated P-fertilized plants flowered earlier than the plants without both $\mathrm{P}$ fertilizer and inoculation, with combined applications of BR 3267 and $30 \mathrm{~kg} \mathrm{P} \mathrm{ha}^{-1}$ reducing the days to $50 \%$ flowering by six days compared with the no $\mathrm{P}$ uninoculated plot (Table 2). P enhances photosynthetic activities of plants and also acts as an energy source for the rhizobium bacteria. Therefore, combining $\mathrm{P}$ and effective rhizobium strains would enhance $\mathrm{N}_{2}$ fixation and rapid growth of the groundnut plant which in turn would stimulate early flower production.

3.2. Nodule Number. Interaction of variety, inoculant and phosphorus was significant at $P<0.05$. The groundnut varieties responded differently to the combined applications of each of the two inoculant strains with $\mathrm{P}$ in terms of nodule number. Combined application of $30 \mathrm{~kg} \mathrm{Pha}^{-1}$ and BR 3267 increased the nodule numbers in Obolo, Oboshie and Samnut 22 by $144 \%, 188 \%$ and $56 \%$, respectively over their respective uninoculated plots. The combined application of $30 \mathrm{~kg} \mathrm{P} \mathrm{ha}^{-1}$ and BR 3267 produced the highest nodule number of 69 in Oboshie which was statistically similar to the nodule number produced by Samnut 22 fertilized with $30 \mathrm{~kg} \mathrm{P} \mathrm{ha}^{-1}$ (Table 3). Uninoculated Samnut 22 with $30 \mathrm{~kg} \mathrm{P} \mathrm{ha}^{-1}$ application produced statistically the same number of nodules as inoculated Samnut 22 fertilized with $30 \mathrm{~kg} \mathrm{P} \mathrm{ha}^{-1}$ (Table 3). The addition of rhizobium inoculants helps boost the number of nodules per plant which in turn increases the potential of $\mathrm{N}_{2}$ fixation with the help of P fertilizer [14]. P fertilizer is required for plant growth and development as it helps in root development and also serves as energy source for the rhizobium which in turn may lead to increased nodule formation thereby enhancing $\mathrm{N}_{2}$ fixation. The results obtained agree with the work by [15] who found out that the nodule number per plant and root length increased when $\mathrm{P}$ was applied in combination with rhizobium inoculation.

3.3. Nodule Dry Weight. The interactive effects of variety and inoculant and that of $P$ fertilizer and inoculant were significant $(P<0.05)$ but the interaction of all the three factors 
TABLE 2: Influence of rhizobium inoculants and phosphorus fertilizer on days to $50 \%$ flowering and nodule dry weight of three groundnut varieties.

\begin{tabular}{|c|c|c|c|c|c|c|}
\hline \multirow[b]{2}{*}{ Groundnut variety } & \multicolumn{3}{|c|}{ Days to $50 \%$ flowering } & \multicolumn{3}{|c|}{ Nodule dry weight (g/plant) } \\
\hline & USDA 3456 & BR 3267 & No inoculant & USDA 3456 & BR 3267 & No inoculant \\
\hline Obolo & 26 & 25 & 29 & 0.271 & 0.587 & 0.240 \\
\hline Oboshie & 26 & 25 & 29 & 0.197 & 0.401 & 0.176 \\
\hline Samnut-22 & 27 & 27 & 29 & 0.342 & 0.406 & 0.317 \\
\hline LSD & & & 0.952 & & & 0.111 \\
\hline $\mathrm{CV}(\%)$ & & & 1.4 & & & 8.9 \\
\hline $0 \mathrm{~kg} \mathrm{P} \mathrm{ha}^{-1}$ & 27 & 27 & 30 & 0.176 & 0.216 & 0.202 \\
\hline $15 \mathrm{~kg} \mathrm{P} \mathrm{ha}^{-1}$ & 26 & 26 & 29 & 0.259 & 0.487 & 0.207 \\
\hline $30 \mathrm{~kg} \mathrm{P} \mathrm{ha}^{-1}$ & 25 & 24 & 28 & 0.376 & 0.692 & 0.324 \\
\hline LSD & & & 0.785 & & & 0.135 \\
\hline CV (\%) & & & 1.9 & & & 28.9 \\
\hline
\end{tabular}

TABLE 3: Interaction effect of rhizobium and P fertilizer on nodulation of three groundnut varieties.

\begin{tabular}{lcccc}
\hline $\begin{array}{l}\text { Groundnut } \\
\text { variety }\end{array}$ & $\mathrm{P}\left(\mathrm{kg} \mathrm{ha}^{-1}\right)$ & $\begin{array}{c}\text { Nodule number/plant } \\
\text { USDA }\end{array}$ & BR 3267 & $\begin{array}{c}\text { No } \\
\text { inoculant }\end{array}$ \\
\hline \multirow{3}{*}{ Obolo } & 0 & 21 & 49 & 27 \\
& 15 & 41 & 60 & 24 \\
& 30 & 49 & 66 & 37 \\
Oboshie & 0 & 17 & 38 & 24 \\
& 15 & 29 & 50 & 27 \\
Samnut-22 & 30 & 44 & 69 & 38 \\
& 0 & 33 & 45 & 39 \\
LSD & 15 & 36 & 53 & 49 \\
CV (\%) & 30 & 44 & 61 & 69 \\
& & & & 10.49 \\
& & & & 16.2 \\
\hline
\end{tabular}

was not significant $(P>0.05)$. Inoculation with $\mathrm{BR} 3267$ produced the highest nodule dry weight in all the three varieties compared to those inoculated with USDA 3456 and the uninoculated varieties. Inoculating Obolo with BR 3267 gave the highest nodule dry weight of $0.59 \mathrm{~g}$ per plant whereas the lowest nodule dry weight of $0.18 \mathrm{~g}$ per plant was obtained when Oboshie was planted without rhizobium inoculation (Table 2). The results agree with the findings of [16] who reported that inoculating soybean with rhizobium produced a higher nodule dry weight than the uninoculated soybean variety.

Nodule dry weight was also influenced when $\mathrm{P}$ and rhizobium strains were applied together. Combined application of each of BR 3267 and USDA 3456 with $30 \mathrm{~kg} \mathrm{P} \mathrm{ha}^{-1}$ gave the highest nodule dry weight in relation to the uninoculated varieties. The dual application of BR 3267 and $30 \mathrm{~kg} \mathrm{P} \mathrm{ha}{ }^{-1}$ produced the greatest nodule dry weight of $0.69 \mathrm{~g}$ per plant with the lowest nodule dry weight of $0.18 \mathrm{~g}$ per plant observed when USDA 3456 was inoculated without $P$ fertilizer (Table 2). The current findings agree with the observation of [17] that inoculating soybean with $B$. japonicum combined with $46 \mathrm{~kg} \mathrm{P}_{2} \mathrm{O}_{5} \mathrm{ha}^{-1}$ increased the mean nodule dry weight per plant compared to the uninoculated treatment. The combined application of the rhizobium strains and the P fertilizer increased the nodule dry weight by about $145 \%$ over the uninoculated (control) plot.
3.4. Pod Load. The interaction between variety and inoculant was significant and $\mathrm{P}$ main effect was also significant $(P<0.05)$ with respect to pod load (i.e. number of pods per plant). However, there was no significant $(P>0.05)$ interaction of variety, phosphorus and rhizobium inoculants with respect to pod load. The three groundnut varieties responded differently to the application of the inoculant strains. BR 3267 produced the highest number of pods in all the three varieties (Table 4 ) and increased the pod numbers by $75 \%, 38 \%$ and $12 \%$ in Obolo, Samnut 22 and Oboshie, respectively over the uninoculated plants (Table 4). Phosphorus application also had a great influence on the number of pods produced by the groundnut varieties . Application of $30 \mathrm{~kg} \mathrm{P} \mathrm{ha}^{-1}$ increased the pod number by $38 \%$ compared to the $0 \mathrm{~kg} \mathrm{P} \mathrm{ha}^{-1}$ treatment (Figure 1). It has been established that application of P fertilizer stimulates node and pod formation in legumes [18] so the $30 \mathrm{~kg}$ $\mathrm{P} \mathrm{ha}^{-1}$ may have caused this increase via increased pod node formation. The observation by [19] that significant increase in pod load in various legume plants were due to increased $\mathrm{P}$ application confirm the results obtained in this current study.

3.5. Pod Yield. There was no interaction between the three factors, namely groundnut variety, phosphorus and inoculant on pod yield. However, the interactions between variety and inoculant and also between $\mathrm{P}$ and inoculant showed significance $(P<0.05)$ with respect to pod yield. Inoculation with BR 3267 produced the highest pod yield in all the three varieties with yields increasing from 13 to $40 \%$ compared to the uninoculated treatments with Samnut 22 giving the highest yield of $2013 \mathrm{~kg} \mathrm{ha}^{-1}$ when the inoculation was with BR 3267 (Figure 2).

P fertilizer cum rhizobium inoculant also had a great influence on the pod yield of groundnut. Inoculating with rhizobium strains in combination with $30 \mathrm{~kg} \mathrm{P} \mathrm{ha}$ produced yields that are much higher than inoculation with rhizobium without P fertilizer. Both USDA 3456 and BR 3267 with $30 \mathrm{~kg} \mathrm{P} \mathrm{ha}^{-1}$ gave statistically similar high yields of $1805 \mathrm{~kg} \mathrm{ha}^{-1}$ and $1757 \mathrm{~kg} \mathrm{ha}^{-1}$ respectively. The uninoculated unfertilized $\left(0 \mathrm{~kg} \mathrm{P} \mathrm{ha}^{-1}\right)$ plots produced the lowest yield of $1074 \mathrm{~kg} \mathrm{ha}^{-1}$ (Figure 3). Increases in yield 
TABLE 4: Influence of rhizobium strains on pod loads of three groundnut varieties.

\begin{tabular}{lccc}
\hline Groundnut variety & \multicolumn{3}{c}{ Pod load } \\
& USDA 3456 & BR 3267 & No inoculant \\
\hline Obolo & 17 & 21 & 12 \\
Oboshie & 18 & 19 & 17 \\
Samnut-22 & 23 & 25 & 18 \\
LSD & & & 3.025 \\
CV (\%) & & & 5.8 \\
\hline
\end{tabular}

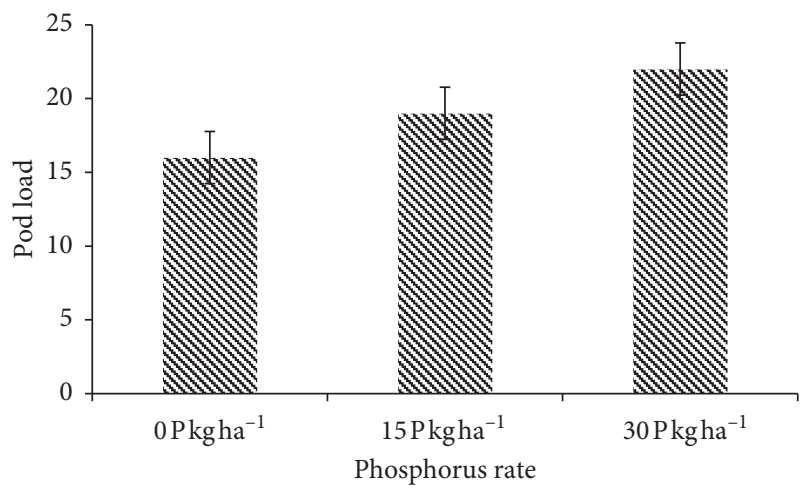

FIGURE 1: Effect of phosphorus on pod loads of three groundnut varieties (the bars represent LSD at $P<0.05$ ).

due to inoculation is evident in most research studies carried out around the world and even in areas where the yield increment is not obvious, inoculation may still have major benefits by enhancing seed $\mathrm{N}$ levels and $\mathrm{N}$ uptake by the plant [4]. According to [20], the combined use of P fertilizers and rhizobium inoculants increased grain yield and enhanced $\mathrm{N}_{2}$ fixation to improve the fertility status of most soils. The present study is in agreement with this finding as the combined use of $\mathrm{P}$ and inoculants increased yields of the test groundnut varieties.

3.6.100-Seed Weight. The variety main effect was significant $(P<0.05)$ in terms of seed weight. However, there were no significant effects $(P>0.05)$ with regard to $\mathrm{P}$ main effect, inoculant main effect and their interactions. Obolo had the highest seed weight of $85.8 \mathrm{~g}$ with the lowest weight of $44.2 \mathrm{~g}$ obtained from Samnut 22 (Figure 4). Each crop variety released has its own attributes and genetic make-up that the breeders focus on when developing it. Research work has shown that both the seeds of Obolo and Oboshie are genetically big with 100 -seed weights of $80.8 \mathrm{~g}$ and $85.6 \mathrm{~g}$, respectively [21]. In this study, only the 100 -seed weight of Obolo was able to match with its passport weight data. The seed weights of both Obolo and Oboshie were respectively approximately twice that of Samnut 22 (Figure 4). The higher pod yield by Samnut 22 compared with Obolo and Oboshie might not be due to a bigger seed size but probably due to a higher number of seeds per pod.

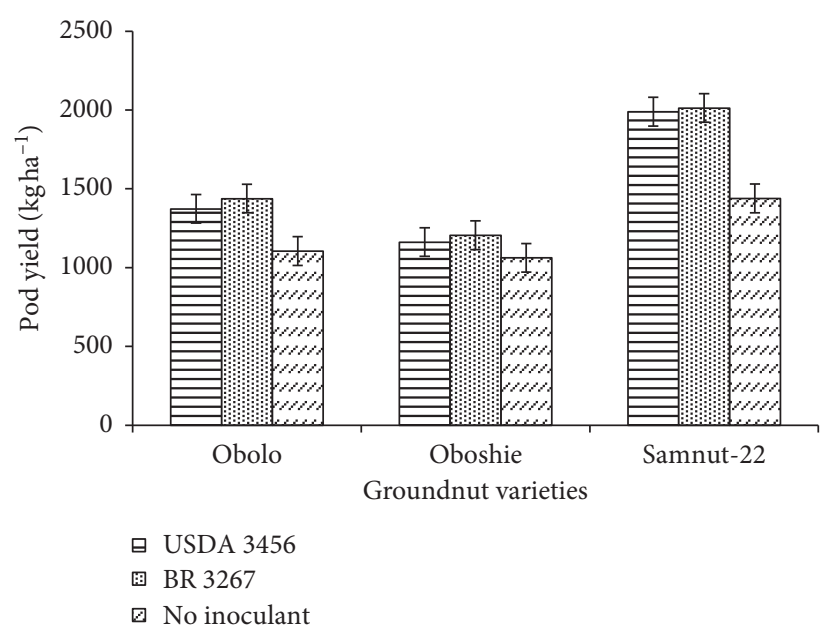

Figure 2: Pod yield responses of three groundnut genotypes to rhizobium inoculation (the bars represent LSD at $P<0.05$ ).

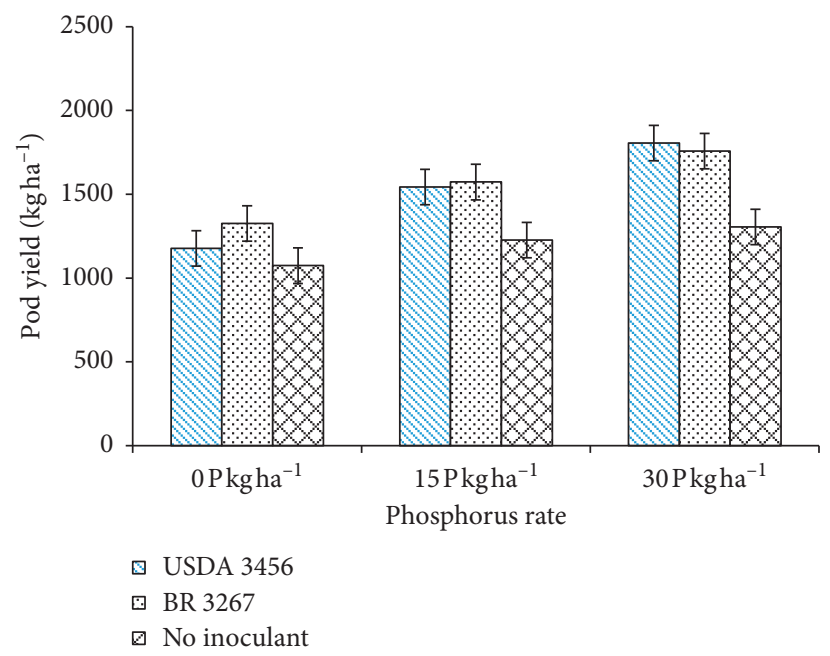

FIgURE 3: Influence of combined application of rhizobium inoculant and $\mathrm{P}$ fertilizer on pod yield of groundnut (bars represent LSD at $P<0.05)$.

3.7. Haulm Yield. The interaction of variety, $\mathrm{P}$ and inoculant with respect to haulm yield was significant $(P<0.05)$ but all the three groundnut varieties responded differently to the application of $\mathrm{P}$ fertilizer and rhizobium inoculation. A combined application of $30 \mathrm{~kg} \mathrm{P} \mathrm{ha}^{-1}$ and USDA 3456 to Samnut 22 produced the highest haulm yield of $6103 \mathrm{~kg}$ $\mathrm{ha}^{-1}$ while the lowest yield of $1756 \mathrm{~kg} \mathrm{ha}^{-1}$ was obtained from the application of $30 \mathrm{~kg} \mathrm{P} \mathrm{ha}^{-1}$ and BR 3267 to Oboshie (Table 5). The result obtained is in agreement with the work done by [22] who reported that combined applications of $\mathrm{P}$ and rhizobium inoculant enhanced straw weight of soybean and other legumes. The combined use of inoculants and $\mathrm{P}$ fertilizers usually enhances nitrogen uptake by plants and this nitrogen helps in the vegetative growth of the plant which might have contributed to the higher haulm yield obtained in this study. 


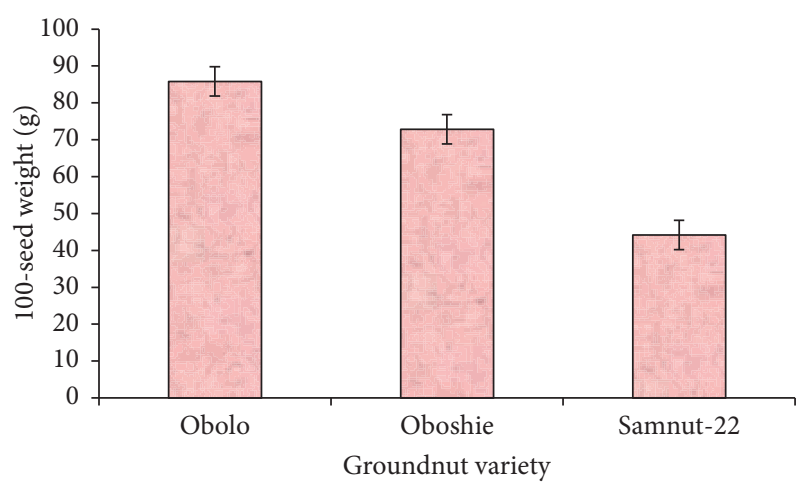

Figure 4: Varietal effect of groundnut on seed weight (the bars represent $\mathrm{LSD}$ at $P<0.05)$.

TABLE 5: Effect of combined application of $\mathrm{P}$ and rhizobium inoculant on haulm yields of three groundnut varieties.

\begin{tabular}{lcccc}
\hline \multirow{2}{*}{$\begin{array}{l}\text { Groundnut } \\
\text { variety }\end{array}$} & \multicolumn{4}{c}{ Haulm yield $\left(\mathrm{kg} \mathrm{ha}^{-1}\right)$} \\
& $\mathrm{P}\left(\mathrm{kg} \mathrm{ha}^{-1}\right)$ & USDA & BR 3267 & $\begin{array}{c}\text { No } \\
\text { inoculant }\end{array}$ \\
\hline \multirow{3}{*}{ Obolo } & 0 & 3456 & 2836 & 1887 \\
& 15 & 2076 & 2844 & 2301 \\
& 30 & 2854 & 2362 & 2429 \\
Oboshie & 0 & 1771 & 3820 & 3889 \\
& 15 & 2912 & 2118 & 3351 \\
Samnut-22 & 30 & 3353 & 1756 & 1823 \\
& 0 & 4524 & 3649 & 5568 \\
LSD & 15 & 4638 & 3274 & 3527 \\
CV (\%) & 30 & 6103 & 3719 & 2757 \\
& & & & 1408.9 \\
& & & & 25.9 \\
\hline
\end{tabular}

\section{Conclusion}

The study found out that all the three groundnut varieties responded differently to both the rhizobium strains and the $\mathrm{P}$ fertilizer applied. BR 3267 was the appropriate strain that was able to enhance nodulation, growth and pod yield of groundnut.

The results obtained in this experiment further confirm the fact that rhizobium strains are host-specific as the groundnut varieties responded differently when they were inoculated with different rhizobium strains. The pod yield of Samnut 22 was higher than that of Obolo and Oboshie though BR 3267 produced the highest yield in all the three varieties. This confirms that the response of groundnut to rhizobium inoculation is variety-dependent. Positive interactions between rhizobium strain and $\mathrm{P}$ fertilizer were observed in this study. Combined application of $30 \mathrm{~kg} \mathrm{P} \mathrm{ha}^{-1}$ and rhizobium inoculation increased groundnut yield by 64 to $68 \%$. Despite the numerous benefits rhizobium inoculation brings to crop plants and agricultural soils, it is faced with unfavourable factors such as erratic rainfall, soil temperature and low-soil $\mathrm{pH}$. There is therefore, the need to research into the appropriate niches and specific host that a particular rhizobium strain can nodulate and fix nitrogen as expected before making recommendations to farmers.

\section{Data Availability}

The data will be made available upon request via mkasante08@ yahoo.co.uk.

\section{Conflicts of Interest}

The authors declare that they have no conflicts of interest.

\section{Acknowledgments}

The authors acknowledge MarketPlace Project and AGRA Inoculant Project in CSIR-SARI for providing support for the research materials used in this experiment.

\section{References}

[1] N. Ahmad, M. Rahim, and U. Khan, "Evaluation of different varieties, seed rates and row spacing of groundnut, planted under agro-ecological conditions of Malakand division," Journal of Agronomy, vol. 6, no. 2, pp. 385-387, 2007.

[2] M. M. Buri, R. N. Iassaka, F. Hedeto, and W. Toshiyuki, "Comparison of soil nutrient status of some rice growing environments in the major agro-ecological zones of Ghana," Journal of Food, Agriculture and Environment, vol. 8, no. 1, pp. 384-388, 2010.

[3] E. V. Tairo and P. A. Ndakidemi, "Possible benefits of rhizobial inoculation and phosphorus supplementation on nutrition, growth and economic sustainability in grain legumes," American Journal of Research Communication, vol. 1, no. 12, pp. 532-556, 2013.

[4] J. Kevin Vessey, "Benefits of inoculating legume crops with rhizobia in the northern Great Plains," Crop Management, vol. 3, pp. 1-10, 2004.

[5] G. Nadia, "Influence of molybdenum on groundnut production under different nitrogen levels," World Journal of Chemistry, vol. 7, no. 2, pp. 64-70, 2012.

[6] M. N. Uma and G. Sathiyavani, "Solubilization of phosphate by Bacillus spp. from groundnut rhizosphere (Arachis hypogaea L.)," Journal of Chemical and Pharmaceutical Research, vol. 4, no. 8, pp. 4007-4011, 2012.

[7] G. W. Mmbaga, K. M. Mtei, and P. A. Ndakidemi, "Extrapolations on the use of rhizobium inoculants supplemented with phosphorus (P) and potassium (K) on growth and nutrition of legumes," Agricultural Sciences, vol. 5, no. 12, pp. 1207-1226, 2014.

[8] B. Ahiabor, S. Lamptey, S. Yeboah, and V. Bahari, "Application of phosphorus fertilizer on soybean [(Glycine max L. (Merril)] inoculated with rhizobium and its economic implication to farmers," American Journal of Experimental Agriculture, vol. 4, no. 11, pp. 1420-1434, 2014.

[9] M. A. Alua, K. Peprah, and G. T. W. Achana, "Climate change implications for crop farming in Ghana's semi-arid Guinea Savanna," International Journal of Development and Sustainability, vol. 7, no. 9, pp. 2334-2349, 2018.

[10] A. Klute, Methods of Soil Analysis, Part 1, ASA, Madison, WI, USA, 1986.

[11] A. L. Page, R. H. Miller, and D. R. Keeney, Methods of Soil Analysis, Part 2, ASA, Madison, WI, USA, 1982.

[12] R. W. Payne, S. A. Harding, D. A. Murray et al., GenStat Release 12 Reference Manual, VSN International, Hemel Hempstead, UK, 2009.

[13] D. Osei, S. Lamptey, C. L. Ayisi, and A. Apraku, "Effects of rhizobium inoculants and growth stages on shoot biomass 
and yield of soybean (Glycine max (L.) merril)," International Journal of Scientific and Technology Research, vol. 3, no. 4, pp. 321-327, 2014.

[14] A. S. Abdulameer, "Impact of rhizobial strains mixture, phosphorus and zinc applications in nodulation and yield of bean (Phaseolus vulgaris L.)," Baghdad Science Journal, vol. 8, no. 1, pp. 357-365, 2011.

[15] R. Badar, Z. Nisa, and S. Ibrahim, "Supplementation of P with rhizobia inoculants to improve growth of peanut plants," International Journal of Applied Research, vol. 1, no. 4, pp. 19-23, 2015.

[16] S. Lamptey, B. D. K. Ahiabor, S. Yeboah, and D. Osei, "Effect of rhizobium inoculants and reproductive growth stages on shoot biomass and yield of soybean (Glycine max (L.) merril)," Journal of Agricultural Science, vol. 6, no. 5, pp. 44-54, 2014.

[17] M. A. Tarekegn and K. Kibret, "Effects of rhizobium, nitrogen and phosphorus fertilizers on growth, nodulation, yield and yield attributes of soybean at Pawe Northwestern Ethiopia," World Scientific News, vol. 67, no. 2, pp. 201-218, 2017.

[18] B. R. Buttery, "Analysis of the growth of soybeans as affected by plant population and fertilizer," Canadian Journal of Plant Science, vol. 49, no. 6, pp. 675-684, 1969.

[19] M. Turuko and A. Mohammed, "Effect of different phosphorus fertilizer rates on growth, dry matter yield and yield components of common bean (Phaseolus vulgaris L.)," World Journal of Agricultural Research, vol. 2, no. 3, pp. 88-92, 2014.

[20] P. A. Ndakidemi, F. D. Dakora, E. M. Nkonya, D. Ringo, and H. Mansoor, "Yield and economic benefits of common bean (Phaseolus vulgaris) and soybean (Glycine max) inoculation in northern Tanzania," Australian Journal of Experimental Agriculture, vol. 46, no. 4, pp. 571-577, 2006.

[21] J. Y. Asibuo and H. K. Adu-Dapaah, "Groundnut variety released," in A Catalogue of Crop Varieties Released and Registered in Ghana, vol. 1, pp. 18-20, 2012.

[22] C. C. Zoundji, P. Houngnandan, M. H. Amidou, F. A. Kouelo, and F. Toukourou, "Inoculation and phosphorus application effects on soybean [Glycine max (L.) Merrill] productivity grown in farmers' fields of Benin," Journal of Animal \& Plant Sciences, vol. 25, no. 5, pp. 1384-1392, 2015. 